This article is a post-review version of the article.

Rachel Morgain (2012): On the use of the uncanny in ritual, Religion, 42:4, 521-548

The published version can be found here:

http://dx.doi.org/10.1080/0048721X.2012.707802 


\title{
On the use of the uncanny in ritual
}

the strangeness of the uncanny offers, demands or presupposes a new way of thinking about religion

- Nicholas Royle, The Uncanny

\begin{abstract}
In 'The Future of an Illusion', Freud suggested that religion allows a person to "feel at home in the uncanny" - that unsettling interplay of suppression and memory that arises from living subject to fears and anxieties in an unpredictable world. Here, I examine a ritual called the 'Wild Hunt' that occurred during my ethnographic research among contemporary Pagans to explore how uncanny encounters within religious rituals can help participants come to terms with fears and anxieties, transforming inchoate emotions stemming from trauma or dislocation. Following Otto, I suggest that such a sense of the uncanny can be central to the power of religious ritual. These uncanny elements within religious ritual provide an illustration of how religious experiences can help participants to feel "at home in the uncanny", thereby bringing together the seemingly disparate accounts of Otto and Freud on the relationship between religion and uncanny experience.
\end{abstract}

\section{Introduction}

An incident I recall as a young adult has come to typify my experience of the uncanny in association with religious ritual. One Easter Saturday - the period in Christian traditions between commemoration of the crucifixion and resurrection - I opened the door to the church in which I sang in the choir to attend choir practice, forgetting for a moment what day of the year it was. During this time, a certain taboo existed around entering the church building, and our choir practice was instead to be held in a nearby office. During the Passion service the day before, the choir's screeching of "Away with him! Crucify him!" and the priest driving nails into a life-sized cross had caused the hairs to stand up on my neck. Now an eerie feeling crept over me as my gaze fell upon an altar stripped bare, where I was accustomed to the elaborate weavings and bright flowers of a ceremonial High Church Anglicanism. Since that point, and through a variety of rituals in several religious traditions, this experience has stayed with me, marking for me a growing awareness of the phenomenology of what Rudolf Otto (1923) once described as the uncanny, terrifying and "aweful" element in experiences of the holy, which he named mysterium tremendum.

Reading on the relationship of the uncanny to religious experience, the most common interpretation of this relationship seems, however, rather far from Otto's holy terror. Noting Sigmund Freud's passing reference to the uncanny in his work 'The Future of an Illusion', several authors have made much of Freud's suggestion that religion is not a source of the uncanny, but rather a response to the (already) uncanny experience of living in a world typified by the "terrors of nature", "the cruelty of Fate, particularly as it is shown in death" and "the sufferings and privations which a civilized life in common has imposed" (Freud 1961: 18):

But if the elements have passions that rage as they do in our own souls, if death itself is not something spontaneous but the violent act of an evil Will, if everywhere in nature there are Beings around us of a kind that we know in our own society, then we can breathe freely, can feel at home in the uncanny and can deal by psychical means with our senseless anxiety (Freud 1961: 16-17).

As literary theorist Nicholas Royle has pointed out, the assumption of Freud's passing reference, and of the more detailed analysis given in his earlier essay on "The "Uncanny"', is that the uncanny is to be interpreted in non-religious terms, something 
arising through profane human experience to which religion is an elaborate response (Royle 2003: 20).

At first glance, these two pictures of the relationship of the uncanny to religion what we might broadly call the Otto approach and the Freud approach - appear at odds with one another. Writing in Germany under the shadow of a war led by Christian nations, Otto's treatise The Idea of the Holy places the uncanny at the centre of religious experience. For Otto, the uncanny is linked to those feelings of awe and dread that mark the most striking component of what he calls the "numinous"1:

'Religious dread' (or 'awe')...first begins to stir in the feeling of 'something uncanny', 'eerie', or 'weird'. It is this feeling which, emerging in the mind of primeval man, forms the starting-point for the entire religious development in history (Otto 1923: 14).

For Otto, experience of the uncanny suggests that there must be something 'real' there - a numinous object towards which this feeling is oriented (Dawson 1989: 288). Freud's essay on 'The "Uncanny"', appearing two years after Otto's work, offers an implicit critique of this theological interpretation. As sociologist Lorne Dawson (1989) argues, Freud's analysis goes a long way towards unravelling Otto's claim that uncanny experience establishes the truth of the numinous object, pointing instead to the possibility of seeing the uncanny as founded in human psychological experience, without recourse to an external primary cause.

Indeed, analysts of the uncanny who have built on Freud's foundation tend to paint a picture of religious belief and uncanny experience as opposite poles of human experience. Royle, in his survey of the notion of the uncanny, quotes an early use of the word from 1815, from Sir Walter Scott's Guy Mannering, in which one was uncanny whose "words dinna seem to come in God's name, or like other folk's" (Royle 2003: 20). Drawing on theorists such as literary critic Terry Castle, Royle suggests that an important component of the meaning of 'uncanny' arose in the wake of the Enlightenment's assurance at human reason and the rejection of religious certainties as the foundation of (European) knowledge (Royle 2003: 21-24). He states that the uncanny "will always have posed a challenge or threat to religious belief" (Royle 2003: 21), underlining this point in a footnote describing an incident from a seminar he was giving on the uncanny at a Finnish university, during which:

A very attentive and articulate student finally put up her hand in sheer frustration: she was a Christian, she said, and had no idea what I was going on about. Nothing, she said, was uncanny for her (Royle 2003: $35 \mathrm{n} \mathrm{68)}$ ).

Similarly, in Brian Clack's paper entitled 'At home in the uncanny' he states:

Given what has been said about the borderline nature of the uncanny, we might simply contend that for the religious believer there is no uncanny, nothing unhomely to experience (Clack 2008: 254).

What then are we to make of Otto's notion of uncanny experience as the earliest indicator of the spectrum of phenomena of religious dread? I would contend that an analysis of religion's relationship to the uncanny stands to gain through incorporating Otto. For there is something very striking about his account that gave his work widespread popular appeal at the time, and has lent it an enduring legacy in the study of religions, despite the many debates surrounding his approach. ${ }^{2}$

1 Otto's notion of the numinous is defined as the phenomenological component of experiences commonly described as 'holy' once these terms are divested of their moral connotations.

2 Although Otto's work had a mixed reception among theologians and scholars of religion of his time, in its idiosyncratic blend of theology and religious survey it has nonetheless left its trace 
In order to explore this further, I draw on an example seemingly far removed from the sober Lutheran world of Otto - a ritual re-creation of the European mythical 'Wild Hunt' which took place during my ethnographic fieldwork in the contemporary Pagan community of Reclaiming, based in San Francisco. In this ritual encounter, I examine how uncanny experience is consciously used to evoke somatic responses in ritual participants in ways that seem to catalyse personal and collective change. While contemporary Paganism is generally more irreverent than the ethos suggested by the weighty concept of mysterium tremendum, my experience of this ritual and subsequent analysis of its role within the ritual cycle of a Reclaiming 'witchcamp' festival spoke to me of the uncanny and the 'aweful' in ways reminiscent of Otto's analysis. At the same time, as we shall see, this ritual's deployment as a tool for psychological transformation points back towards Freud's approach. Drawing on elements of both Otto and Freud can thus help explain the use of the uncanny in this ritual, in ways which I suggest not only allow exploration of the phenomenological dimensions of Otto's inquiry3, but which can help put flesh on the bones of how it is that through religion we can come to feel "at home in the uncanny."

\section{The Uncanny}

Written nearly a decade before 'The Future of an Illusion', Freud's essay 'The "Uncanny"' furnishes us with a useful starting point for locating uncanny experience. Tracing the concept through a series of etymological steps, Freud defines the uncanny as "that class of the frightening which leads us back to what is known of old and long familiar" (Freud 1976: 620). To draw this out, he explores the meanings involved in the German word 'unheimlich', and its opposite 'heimlich', meaning homely or familiar, at first suggesting that unheimlich might be expected to refer to what is unfamiliar. ${ }^{4}$ Yet, as he points out, clearly many things that are unfamiliar are not uncanny - to be uncanny, something else must be added. For this, he works through multiple layers of meaning ascribed to the notion of heimlich, eventually arriving at a definition as that which is secret and even dangerous, evoking what lies hidden behind closed doors. Thus a certain ambivalence is signified in these terms through their equivocal and unstable opposition, such that "heimlich is a word the meaning of which develops in the direction of its ambivalence, until it finally coincides with its opposite, unheimlich" (Freud 1976: 624). This leads him to a second definition, taken from Schelling, for whom unheimlich "is the name for everything that ought to have remained...secret and hidden but has come to light" (Freud 1976: 623).

Freud explores a wide range of examples of uncanny phenomena as they appear both in literature and in the everyday, suggesting that uncanny experience arises when people are confronted with events they have suppressed or beliefs they feel they had superseded. He argues that "if psycho-analytic theory is correct...that every affect belonging to an emotional impulse is transformed, if it is repressed, into anxiety", then the repetition of that repressed experience is likely to evoke further anxiety regardless of "whether [it] was itself originally frightening or whether it carried some other affect" (Freud 1976: 634). Thus he suggests the feelings of dread associated with experiences

on an array of religious scholarship, both theological and non-theological. See Raphael (1997: 1-24, 73-75) and Poland (1992) for discussions of Otto's popular appeal and his influence on cross-disciplinary religious scholarship of the twentieth century.

3 For outlines of the relationship between the phenomenological and theological dimensions of Otto's work see Raphael (1997: 16-17) and Dawson (1989: 288-289).

4 While the shades of meaning between the German and English terms differ, this idea of the uncanny as being uncomfortable enough to be also 'unhomely' seems resonant with the term 'uncanny' and its English-language associations of the 'haunting', 'ghastly' and 'dreadful'. 
that we call uncanny arise because a given experience touches on this amorphous anxiety. Likewise, Freud argues that the uncanny is experienced when events evoke for people "superstitious" notions that (they believe) rational understanding is meant to have overcome, such as those associated with unexpected repetition and coincidence, and most especially those associated with the possibility of continuing existence after death (Freud 1976: 631-635). Thus he concludes that uncanny experience arises when what should have remained secret comes to light, either when "infantile complexes which have been repressed are once more revived by some impression, or when primitive beliefs which have been surmounted seem once more to be confirmed" (Freud 1976: 639).

Much recent academic discussion in this area has focused on the uncanny as a constructed device. Often taking Freud as their starting point, theorists have analysed the use of the uncanny in performance, visual art, architecture, and especially in literature. ${ }^{5}$ Among other themes, analysts have drawn out the strange conceptual and temporal doublings in Freud's account. Linking the uncanny and the fantastic in literature, for example, Borghart and Madelein (2003) explore the hesitations and foldings of time and memory suggested in both literary categories. Anthony Vidler, examining the uncanny in architecture, highlights the crossings and fissures within spatial and conceptual oppositions such as exposure and concealment, home and homelessness, further suggesting a connection of the aesthetics of the uncanny to estrangement and the "shock of the modern" arising from the social traumas of the twentieth century (Vidler 1992: 9, 167-175).

Of particular interest here is what David Kennedy, in an analysis of elegy, observes is an association of the uncanny with desire, and how uncanny experience seems both to draw us in and draw us out beyond ourselves. Drawing on Lacan, he points to what he calls the "combination of lack, surplus and negative space" that he sees as characteristic of both (Kennedy 2009: 583). Since for Lacan, the lost object of desire (originally the unconditional love the infant demands from the Other that arises through the infant's growing awareness of separation from the Other) can never be attained, the distance from the object of desire is central to the experience of desire (Kennedy 2009: 583-584). In this analysis of desire as rooted in originary self-awareness, where "the 'before' of the subject reappear[s] as the 'beyond' of the subject", we see echoes of Freud's definition of the uncanny as the return of what has been repressed:

[I]f the uncanny is what Freud terms 'that species of the frightening that goes back to what was once well known and had long been familiar', then from a Lacanian perspective what drives the uncanny is the self apparently well known and familiar - suddenly being confronted with the moment of its becoming out of non-being, and therefore with the originary moment of desire (Kennedy 2009: 584).

Illustrating these psychological insights through elegy, he points to the evocation of the uncanny in this literary form as arising from this inchoate field of desire and loss.

Using an approach that understands ritual as a form of performance, such insights on the uncanny as an aesthetic or literary device are valuable for interpreting the Wild Hunt ritual I describe here. Yet, in analysing this ritual as performance, it is also important to recognise that it is, primarily, a religious experience. This raises a central question beyond the broader treatment of the uncanny in art and literature - that of the specific relationship of religious experience to the category of the uncanny. In exploring this issue, Clack's (2008) analysis of religion's role in allowing us to feel "at home in the uncanny" offers a useful starting point. Building on Freud, Clack suggests that religion can help people face the sense of pervasive anxiety that arises from being a human in a

${ }^{5}$ See Masschelein (2003) for a discussion of Freud's precipitative role in this literature. 
world that threatens our very being. He begins by proposing that between the poles of certainty associated with religious belief on the one hand and naturalistic rationalism on the other is a "borderline experience" of intellectual uncertainty, a "trembling of belief" that the religious believer can avoid through embracing a worldview "by means of which everything makes perfect sense" (Clack 2008: 253,254). He further points out that Freud's comment is not simply a comment on religion, it is also a claim about the unhomely nature of the "modern human condition" (Clack 2008: 255). Drawing on Martin Heidegger's notion of Dasein, Clack suggests that human existence involves being 'thrown' into a condition in which our possibilities are determined by our situation. According to Heidegger, in this condition of the facticity of Dasein, what first appears as the "tranquilized self-assurance" associated with the familiar can easily collapse into the unfamiliar, thereby giving rise to the uncanny experience of feeling not at home (Clack 2008: 255). Thus Clack suggests that we can see religion as a strategy for responding to this existential uncertainty. He quotes Michael Oakeshott on this point, who contends that "the gift of a religious faith is that of a reconciliation to the unavoidable dissonances of a human condition" (Clack 2008: 256).

The second aspect of the uncanny outlined by Freud - that of surmounted beliefs seemingly confirmed - points us to a further dynamic of this relationship. For while Freud's focus is mainly upon those beliefs generally designated in European modernity as 'magic' or 'superstition', in social conditions where secular assumptions have to some degree become hegemonic, religious beliefs themselves can at times be experienced as uncanny, both when their form is encountered by those for whom their underlying rationale has been eroded, and for the way that they re-occur through the actual pervasiveness of their ongoing cultural influence. Thus Royle's survey of the uncanny dedicates two chapters to exploring the uncanniness of particularly Christian experience in modernity, including one he calls "The private parts of Jesus Christ" (Royle 2003: 277306). He points, for example, to the way Christianity haunts Derrida's writings on the uncanny in Spectres of Marx (Royle 2003: 283), and to the destabilising effects of the discovery of the Nag Hammadi library (the 'Gnostic Gospels') on our fundamental assumptions (still somehow foundational in a secular age) about the essence of Christianity (Royle 2003: 283-286). In these examples, we see his analysis of the Enlightenment notion of uncanny as that which rejects Christian belief turned around, such that religious ideas themselves come to seem uncanny in a context where cultural assumptions have supposedly superseded them.

Underpinning these approaches is the opposition Freud understood to exist between religious certainty and uncanny experience. Yet to account more fully for the dimension of uncanniness in the religious ritual outlined here, it seems important, too, to address Otto's identification of the uncanny tremendum as primary religious experience. As feminist theologian Melissa Raphael suggests, despite fundamental theological differences, it is possible to locate a corresponding notion to Otto's tremendum within modern Goddess spiritualities such as that discussed here, where it is associated with the central figure of the destroyer Goddess or Crone (Raphael 1996: 34). Anthropologist Tanya Luhrmann, exploring this ubiquitous phenomenon of what she calls the "ugly Goddess" in modern Paganism, similarly evokes Otto's identification of divinity as "wholly other" to explain these violent images, further pointing to how frightening images of deity help give narrative form to inchoate experiences of pain and trauma (Luhrmann 2001: 127-132).

Recent ethnographies have also depicted daunting elements within Pagan ritual. As examples of the 'aweful' within ritual, they demonstrate, too, how embodied experience of ritualised danger can confront participants with their own fears. Susan Greenwood's account of another Wild Hunt ritual in a British Pagan community touches on how 
participants were confronted with their unconscious fears in the darkness of the wood they traversed (Greenwood 2005: 119-142, particularly 132). ${ }^{6}$ Likewise, Douglas Ezzy's description of a Pagan community's "Underworld Rite" of Persephone and Hades explores how a liminal encounter with the anticipation of being snatched to the underworld transformed participants' fears surrounding death and loss, confronting them with their "somatically experienced emotion" of deep-set insecurities about their own mortality (Ezzy 2011b: 257). These examples illustrate the quality of mysterium tremendum within Pagan ritualisation, while highlighting opportunities such encounters offer for psychological transformation. In fact, the Wild Hunt ritual I attended spoke to multiple, enfolded levels of participants' experience - embodied, emotional, social and environmental - pointing to the complexity of such ritual encounters. How these manifold somatic and cognitive processes work seems worth exploring more fully, including with reference to their uncanny quality, with its hesitations, foldings, surplus and lack.

\section{The Reclaiming community}

Before going on to describe this Wild Hunt ritual and analyse its invocation of the uncanny, I turn now to the context in which it took place: the Reclaiming community. ${ }^{7}$ Reclaiming is a Wiccan-influenced tradition within the broader contemporary Pagan movement that has spread through Euro-American societies from the latter part of the twentieth century. ${ }^{8}$ Like many other forms of contemporary Paganism, Reclaiming's ritual calendar involves a yearly cycle of eight festivals or 'sabbats' placed at the solstices, equinoxes and the four 'cross-quarter' days in between. Ritual themes are drawn in particular from a British Romantic pastoral imaginary, tied to the idea of the Earth's fertility as waxing and waning with the seasons. At Summer Solstice, the sun-God Lugh (a Celtic deity) is thought to die, to be reborn again at Winter Solstice. At the equinoxes, Reclaiming members commemorate the descent of the ancient Greek Goddess Kore into the Underworld, the blighting of the Earth by her mother Demeter, and Kore's return from the Underworld as Persephone. ${ }^{9}$ While the central deity in Reclaiming is 'the Goddess' - practitioners' term for what they see as the sacred, unfolding, interconnected cosmos - Reclaiming members understand all religions, particularly those which they see as Earth-based, as expressing essential religious

6 The Wild Hunt is a popular mythological theme in many Pagan traditions. I agree with Greenwood's central contention that the Hunt helps create a sense of connection among participants to the spiritual and natural worlds, but suggest that the particular association of this ritual to uncanny experience and the use of uncanniness in helping effect transformations in disposition and awareness are worth exploring further.

7 This paper arises out of a broader ethnographic study within the Reclaiming community conducted through the Australian National University, which provided ethics approval and funding. It was carried out with permission from Reclaiming teachers, ritual leaders and witchcamp organisers in Northern California. The central component of my field research as a participant-observer took place in California from 2006-7. Several Reclaiming members have read and commented on drafts of this paper.

8 For accounts of the provenance of Wicca in Britain and its influence on Paganism in the US see Hutton (1999) and Clifton (2006), respectively. Reclaiming's most immediate Pagan predecessor is the Fairy or Feri tradition founded by Victor and Cora Anderson. As Clifton (2006: 129-132) suggests, it is clear that the Andersons drew many ideas and practices from British Wicca, including the primary calendar and ritual structure. Jone Salomonsen's (2002) ethnography of Reclaiming contextualises Reclaiming's origins in terms of wider developments in contemporary Paganism and feminist spirituality in Europe and North America.

9 See Williams (1985: 248-254) for an analysis of the influence of Greek mythology on nineteenth and twentieth century British Romanticism. 
truths. As such, they are highly eclectic, drawing symbols, myths and ritual themes from a wide range of pre-Christian European, Native American, Semitic and other religions, with the Celtic and Greek pantheons being particularly popular.

Reclaiming is centred on a practice of instrumental ritual magic, in which rituals are aimed at achieving specific ends structured by the ritual 'intention'. This can take the form of spell-casting or other rituals for specific, narrow purposes, such as a ritual for winning a job or for healing after a divorce, usually performed individually or in small groups. More prominently this is expressed through festivals such as the public rituals held at the eight sabbats, which combine celebration of the occasion with activities directed towards achieving the intention set by the ritual planners, designed to encompass broad goals of both a personal and social nature. Reclaiming rituals are highly participatory, the primary form following that of the British Wiccan traditions (although typically exhibiting less formality) with 'sacred space' created through grounding, casting a circle and invoking elements, deities and other spiritual allies, followed by the central instrumental ritual activity. In a cultural context where adherence to modern scientific principles is expected, this emphasis on instrumentality offers practitioners a defence for their beliefs in ancient spirits, deities, fairies and other mythical figures: at the very least, such mythical elements are judged to be 'true' because they are useful as psychological tools, as symbols aiding in healing and in other forms of personal and cultural transformation. In practice, most practitioners give greater existential weight to these entities, viewing them as real and formidable, and as placing considerable claims upon their lives. While deities and spirits are invoked or 'channelled' by human participants ${ }^{10}$, this process is seen to invite their real presence into the ritual, introducing a sense of enchantment and unpredictability. Furthermore, Reclaiming teachers and priestesses are highly skilled at leading participants into altered states of consciousness, using a wide range of techniques such as guided visualisation, chanting and ecstatic dancing, lending power to rituals and credence to the idea that the 'energy' raised in the ritual can be directed towards specific, instrumental ends of personal and social change.

While Reclaiming members share many ideas and practices with other forms of Paganism, in contrast to many other traditions, Reclaiming's core members and teachers widely view themselves as engaged in a radical project to transform modern Western society, which they view as fundamentally violent, warlike and environmentally destructive, riddled with patterns of domination and alienation. Reclaiming emerged around 1979 in the San Francisco Bay Area from the ferment of counterculture and radical politics that had swept the city throughout the preceding decade. In its early days, many members took part in and were influenced by the San Francisco anarchist coffee house meetings and the direct action movements of the Abalone Alliance and Livermore Action Group - networks of anarchist and feminist-influenced activists in the early 1980s which developed in opposition to nuclear technology, in particular the building of a nuclear power plant at Diablo Canyon and the nuclear research work of Livermore Laboratories (Epstein 1991; Hauser 2003). At the time of Reclaiming's founding, several Pagan and Wiccan groups already existed in the Bay Area, including the New Reformed Orthodox Order of the Golden Dawn and the Feri Tradition (Clifton 2006: 111-133). Reclaiming's founding members drew from these Earth-based spiritualities and from a growing feminist spirituality literature signalled by the publication of works such as Mary Daly's (1978) Gyn/Ecology and Christ and Plaskow's

10 'Channeling' or 'aspecting' within Paganism is seen as a means of inviting deities or other spirits to work through the body of the practitioner while part or all of the practitioner's ordinary consciousness is displaced. This technique was used extensively at the event discussed in this article. See Ezzy (2011a) for an ethnographic account of channeling as a form of spirit possession within Pagan ritual. 
(1979) WomanSpirit Rising, melding this with the anarchist politics and methods of participatory democracy of the direct-action movement to form a unique tradition of Paganism bent on radical social transformation. Despite a broadening membership base that has diluted some of its more revolutionary foundations, this focus on social change remains central among many core practitioners, while the activism, books and writings of Reclaiming's most famous priestess, Starhawk, continue to draw in layers of new members from Earth-activist and other radical political communities.

Central to this Reclaiming focus on social transformation is their theology of 'immanence', which teachers see as very different from the emphasis on 'transcendence' in major world religions, particularly the Judaeo-Christian traditions. For Reclaiming teachers, immanent theology places sacrality primarily in the material world, particularly in the natural world and in human beings. As Starhawk describes this:

[T] he consciousness I call immanence [is] the awareness of the world and everything in it as alive, dynamic, interdependent, interacting and infused with moving energies: a living being, a weaving dance (Starhawk 1982: 9).

Thus she explains:

When I say Goddess I am not talking about a being somewhere outside of this world, nor am I proposing a new belief system. I am talking about choosing an attitude: choosing to take the living world, and the people and creatures on it, as the ultimate meaning and purpose of life, to see the world, the earth and our lives as sacred (Starhawk 1982: 11).

Reclaiming members believe that Christian theologies of transcendence have divested the natural world and human beings of the respect due to their innate sacredness, conceptualising objects and persons as merely 'things', thereby paving the way for the social injustices and widespread environmental exploitation that they see as characteristic of industrial modernity. They feel that their own emphasis on the immanence of the sacred, in reinvesting the natural world and all human beings with sacrality, is more likely to inspire practitioners to care for the Earth and to focus them on achieving social justice.

Less obviously, but no less centrally, Reclaiming is also distinctive among Pagan traditions for its extensive use of stories such as fairy tales to frame and anchor their ritual practices. While this method influences many Reclaiming rituals and classes, it is most apparent at the festival retreats known as witchcamps. The story upon which a particular witchcamp will be based is announced in advance to allow participants to familiarise themselves with various versions and with the mythical elements which surround it. Camps are developed around these themes, with priestesses, teachers and camp participants drawing elements from the tale and from the surrounding mythos to build their rituals and classes, and to interpret their experiences. In particular, each witchcamp has a story arc expressed through the camp-wide rituals held in the evenings, which are designed to take participants through stages of descent, challenge, and recovery to facilitate psychological transformation. These settings are structured to encourage participants to address often tenacious issues of emotional and psychological concern, with teachers and priestesses seeing the closed, set-apart environment of witchcamps, and the intensive use of ritual techniques, as powerful means of catalysing members' healing from the psychological traumas induced by living in a destructive society. These experiences are often powerful, and many supports are put in place in recognition of the emotional challenges that can arise for participants during the week, such as the small 'affinity' groups that meet each afternoon to provide personal support to aid campers' emotional work.

There are many purposes behind the use of stories to frame Reclaiming activities. Reclaiming priestess Hillary Valentine has this to say about the use of fairy tales: 
The fairy stories are told from a completely different cultural and psychological perspective than our modern one. In these stories women and men and even little children each have their own powers, cleverness, and magical abilities. The natural world is a great resource that helps those who respect and care for it and punishes the selfish and exploitative... The stories don't recommend a spiritual way of life; instead, they assume a spiritual way of life. There is much we modern people have to learn from the assumptions of these ancient tales (Starhawk and Valentine 2001: 25-26).

Reclaiming rituals are designed to encourage a "spiritual way of life" that blends respect for the earth and other living beings with a fuller sense of personal wellbeing and alignment with spiritual values. Starhawk and Valentine's handbook Twelve Wild Swans quoted here involves instructions for interpreting the tale of the book's title through both the "inner" and "outer" paths of personal and social transformation, the two paths being seen alike as necessary facets of the same overall project. Without a focus on healing the self, Reclaiming members believe people are certain to perpetuate the social ills they have internalised through the damage done by modernity. Their ritual work is thus focused as much on personal healing and transformation as on social justice. 11

Thus of equal importance for Reclaiming teachers is the capacity for fairy tales to render psychological problems in symbolic terms. As psychologist Bruno Bettelheim argues:

In fairy tales, internal processes are translated into visual images. When the hero is confronted by difficult inner problems which seem to defy solution, his psychological state is not described; the fairy story shows him lost in a dense, impenetrable wood, not knowing which way to turn, despairing of finding the way out (Bettelheim 1977: 155).

Bettelheim points to J.R.R. Tolkien's four essential elements of fairy tales - fantasy, recovery, escape and consolation - suggesting that the psychological value of these tales rests upon taking listeners through a process of "recovery from deep despair, escape from some great danger, but, most of all, consolation" (Bettelheim 1977: 143). When rendered in ritual form as they are in Reclaiming, these tales thus have enormous potential for aiding processes of healing and psychological change.

How Reclaiming members approach such questions of psychological change has been variously influenced by an eclectic array of concepts and theories drawn in part from established psychoanalytic traditions. As historian Wouter Hanegraaff has suggested, psychoanalytic tropes, such as the importance of bringing unconscious ideas into consciousness, have been highly influential within contemporary Paganism, including through the work of Starhawk (Hanegraaff 1996: 215-219). While Freudian ideas have had an important impact, those of Jung have been more central still, for example in the conception of the unconscious not only as a site of repression, but as a potentially valuable storehouse of individual and collective knowledge (Hanegraaff 1996: 217, 496-513). Furthermore, the influence of post-Freudian theories of Wilhelm Reich can be seen in the emphasis given to bodily movement as a means of shifting habituated psychological dispositions. ${ }^{12}$ Nevertheless, there are also important

\footnotetext{
11 Salomonsen, for example, discusses the centrality of personal psychological transformation in Reclaiming with respect to the central rite of initiation, which Reclaiming members may choose to undergo as a significant commitment to Reclaiming spiritual values (Salomonsen 2009).

${ }^{12}$ Reich's unconventional theories focus on using bodily movement to free what he called "orgone" energy or life force from the cumulative effects of authoritarian social structures upon bodily "armoring". See Clifton (2006: 62-64) for a discussion of how Reich's thought has intersected with and influenced US Paganism since the 1970s.
} 
differences from psychoanalytic methods, in particular that processes aimed at personal transformation in Pagan traditions such as Reclaiming take ritualised form, relying heavily on lateral symbolic and somatic methods over discursive, analytic ones. So while Reclaiming rituals draw on psychoanalytic ideas in important ways, as can be seen below in the pattern of tapping into unconscious memories through catharsis, they also reshape these ideas and methods quite profoundly, by drawing them into a distinctive blend of highly imaginative, embodied and sacralised modalities of ritual healing.

The particular event described in this paper took place at a witchcamp in California during my field research. The California Witchcamp involves over 100 participants attending intensive ritual activities for one week in a closed environment in the redwood forests of Mendocino Woodlands. Days are structured by morning classes involving two teachers and around twenty campers in one of four or five smaller 'path' groups, and evening rituals involving all campers, built upon the camp's central story theme. The camp I describe here had the theme of 'Avalon', based upon the Arthurian legends, and in particular the feminist reproduction of this tale by Marion Zimmer Bradley in The Mists of Avalon. In Zimmer Bradley's story, the central figure is Morgaine, depicted as a priestess of the ancient Goddess religion in the process of being supplanted by Christianity, whose temple is hidden behind the mists at the summit of Glastonbury Tor. ${ }^{13}$ In the story arc of this camp, this theme was interwoven with the Welsh version of the legend of Gwyn ap Nudd, who was prominent in early Arthurian tales, and who according to later traditions was driven from Glastonbury Tor by the use of Holy Water. In Welsh tradition, Gwyn ap Nudd is also seen as the leader of the Wild Hunt, leading baying hounds to harvest human souls. In the Avalon camp, this psychopomp role was invoked as a means of precipitating our imaginative 'descent' into the underworld of Anwnn, which according to this story is inhabited by the fairy folk or 'fey', who have magically avoided centuries of encroachment by Christianity and modernity by retreating to the space under Glastonbury Tor. There we came to pledge our fealty to the land and to renew the 'old' treaty that once existed between humans and the fairy folk.

\section{The Wild Hunt}

The ritual of the Wild Hunt transpired in the early part of the Avalon witchcamp sequence, instantiating our 'spiral downward' into the world of the fey. At the gathering of the ritual, we were introduced to the Fairy King Gwyn ap Nudd with the following description: ${ }^{14}$

Once they say he lived under the mountain.

They say he still lives there.

And he would come out on stormy nights to lead the wild hunt, lead the hounds through the thunder and the fog,

\footnotetext{
${ }^{13}$ Glastonbury Tor is a real location in Somerset in the UK, around which many myths of the Arthurian legends have gathered, including the belief that King Arthur's and Gwynevere's graves lie in the nearby Glastonbury Abbey. In this mythical recreation at the California witchcamp, we imagined ourselves travelling to Glastonbury Tor and into the space under the Tor where, according to myth, the fairy underworld of Annwn is located.

${ }^{14}$ Owing to the difficulties of writing extensive field notes while participating in Reclaiming rituals, and the ban that exists on the use of recording devices during Reclaiming rituals, quotes given from my field notes covering ritual activities were written as soon as possible after the ritual took place - usually later that night or the next day. While I am therefore unable to reproduce the exact wording used in these events, I believe my recording of them reflects as nearly as possible the sense and meaning conveyed and many of the concepts and words used, if not their exact form.
} 
to gather up the lost souls, to gather up the dead.

They say he still does.

We were then instructed to walk the labyrinth next to the ritual circle where we gathered, reflecting on what we were afraid to see, on whether we were prepared to face the dark. As I did so, wondering if I had not already looked into the dark enough for now, I fell into what I later called 'serious trance'. This is an excerpt from my notes of this experience:

The wolves howling half way thru my walk sent shivers up me, and as the hounds drew closer and I realised they were indeed people - the fairy people dressed in white with red-lined eyes - I knew the next stage was entered. I knew I should follow them - and I was cast out with the small band into the night. The fey went back to gather the next lot, and we walked under the light/darkening sky.

...I walked through the 'village' of huts [the camp cabins], one with its lamp on. The howling of the hounds raised my hackles, and I imagined the restful people of the village sleeping while Gwyn ap Nudd rode past to call the unfortunate - or the fortunate - to ride with him... I heard a couple of people inside one of the huts, chatting and laughing, as though nothing was going on outside.

I walked a clockwise circle around our path place [a grassy circle surrounded by trees where the morning classes of my group were held], and then made my way down to the river. I feel courageous, but I was feeling the fear too, walking through the dark alone, while wolves and hounds howl about me. It's a new thing for me to face the dark in this way. Such a small step, compared to what the real dangers are.

As I clambered over the wood leading to the bridge, a little shaky in my footing in the dark, I felt the presence. As I stood on the bridge gazing into the dark water, I stood in deep trance, aware of the lady of the lake in her dark self of night time.

The horn blew, calling us back to the circle. I felt pulled, wanting to stay. I climbed back up the bank, but turned back before I left, held to a tree, looking over the still, dark water through the branches of the redwood tree, and thought of the Lady of Shalot. And thought of Ophelia drowning. And wondered at these tales. And realised the words: 'People have drowned in lesser waters than this.' No matter how murky the waters are...the sword must break the surface regardless.

[Back at the circle] We travelled - ran (!) - thru the night, and entered the land of the fey, under the tor, in the hollow space under the hill (they say it's still there). And when we were there, we were invited to walk the fire, to see the connections with our hazily-set eyes - connections of ourselves to this place [of the fairy country].

As I later learned, the plan of the Wild Hunt was that participants would follow the hounds in groups of around eight to ten, each led by a camp teacher in a ritual experience inspired by their particular circumstances. Approximately half the camp participated in this way, walking for long distances in the dark, across the creeks and into the wider reaches of the camp territory, stopping to undertake a trance journey or ritual activity shaped by the inspiration of the group and its teacher, later returning to bring their experiences together in the ritual circle. For others such as myself, the very structure of the ritual - the chaotic way in which groups were drawn out by the hounds running through - led us to into solitary experiences. One teacher later observed to me 
that it was the combined effect of these many different experiences, brought back together in the ritual circle, which led to the power of the final ritual trance. While the framing of the ritual followed the recognisable Reclaiming pattern, the accidental nature of events at its core allowed for these markedly different experiences, which were nevertheless united by the howling of the hounds and the journey in the darkness.

It is worth unpacking the components of this experience that create the atmosphere of uncanniness I felt in this ritual. Here, elements of familiar, chilling tales in the European mythos - the howling of the hounds, the potency of being 'cast out' to wander in the dark - combined to create a sense of being in a 'haunted' or 'ghastly' setting. As I walked through the camp cabins, this generated an eerie impression of unfamiliarity surrounding the otherwise cosy and innocuous-seeming cabins of Mendocino, evoking dimly-remembered memories of fantasy tales of adventure in which the dangerous outdoors stands in stark contrast to the warm, inviting heimlich interior. At the same time, the secretiveness associated with the German concept of heimlich is here suggested in the laughter and half-heard voices inside the cabin, hinting at a safe, exclusive world to which those of us outside might have no access (to this day I am unsure as to the source of these voices: whether those of camp participants choosing to miss the ritual, or the product of my active imagination, or something else).

Intersecting with these cultural elements is the expectation camp participants bring to a ritual setting such as this, which allows for solemn participation in an experience that might otherwise be treated as melodramatic, comic or more passively as a 'show' to be watched rather than an event to be participated in. Reclaiming classes and rituals teach participants the value of learning to enter a trance-state at the start of a ritual, which in this case was encouraged further by the invitation to walk the labyrinth - a practice seen as best done in trance. The labyrinth likewise references for many Reclaiming members the spiritual feminist trope of a journey 'inwards' to find the 'shadow' within - a term derived from Jung to refer to the conglomeration of all that is frightening or revolting within the unconscious, which the conscious personality has rejected.15 Furthermore, the Wild Hunt took place as the second ritual of the week, which long-term camp participants would recognize as the ritual designed to take them 'down' into the 'dark' through the layers of their culturally-sanctioned personas to dig up whatever is in their shadow so that it can be recognised and integrated through the rest of the week. The ritual intention for that night, which was posted on the wooden wall of the central dining cabin, reinforced this overarching expectation:

To relentlessly unmask as we embrace the dark mystery and enter the Realm of Annwn.

Thus the expectation established by Reclaiming custom and by the teachers' framing of this ritual is that it would conform to the following pattern: a solemn occasion tapping into intense and difficult feelings, which have lain dormant, hidden or suppressed by people's traumas and the alienating effects of social conditioning in modernity, and which are now ready to surface, to be acknowledged and transformed.

The dimensions of transformation touched on in this ritual were of both a personal and a social nature. Upon our return to the ritual circle following the encounter with the Wild Hunt, the priestess led a trance that spoke of betrayals and broken alliances, calling

\footnotetext{
${ }^{15}$ Shekhinah Mountainwater's (1991) spiritual feminist workbook Ariadne's Thread is familiar to many Reclaiming members, and gives a characteristic account of this role of the labyrinth as it is understood in spiritual feminist circles. Luhrmann (2001) describes a similar framework surrounding the notion of the 'dark Goddess' among spiritual feminists as representing an inner core of unpleasant or socially unacceptable feelings for women buried underneath layers of social conditioning. In the Reclaiming case, the model of the shadow applies equally to men and women.
} 
us to think of the devastating effects of US-led wars, of the Iraqi mother crying for her children. She said, "We are destroyer and destroyed", and many participants shouted their outrage and anger. In the content of these words, and in the emotions expressed in response, we find a resonance with the sense Reclaiming participants have of being part of what they see as a destructive society - both victims of that destructiveness and culpable for it. During this section of the ritual, huge and seemingly powerfully cathartic displays of emotion could be seen across the circle from many of those present. This ritual encounter with the uncanny in the Wild Hunt was thus aimed at catalysing both psychological and social transformations.

\section{Ritualised uncanny experience as psychological transformation}

The release of emotion seen in the ritual circle after the Wild Hunt speaks to how its unsettling dynamic seemed to tap powerfully into deeply personal dimensions of participants' experience and memories. For one participant, Erin, this was particularly potent. In an interview recorded soon after returning from witchcamp, she gave an account of her experience that illustrates this process of personal transformation triggered by the unsettling context of this ritual:

A challenge for me in my life is my history of sexual abuse and in this setting of witchcamp a lot of that was coming up for me because, in the past, I had had a negative sexual experience at a Pagan gathering... I wasn't expecting it to come up for me as strongly as it did, but it did come up for me very strongly.

And in one of the rituals...at the beginning of the week, I really got in touch with a lot of grief and anger around that. And I had a big emotional release, and I was crying, and it was very cathartic... And I had rage and, you know, I feel like I moved a lot of energy.

That was the night that they did the running around, when we went under...into the fairy underworld, and the wolves were running around. And then, at the circle after that when [the priestess] was leading the trance, I can't remember what she said that evoked it in me, but I just started crying. And I was really, really sobbing, and, really, really moving a lot of energy. And I thought that I might have to leave the circle, I didn't know if I was going to be able to compose myself enough to participate in the rest. But I just said to myself, you know, give it five more minutes, give it five more minutes, because I really wanted to take advantage of the energy and the container that was there...

...So I'm grieving, I'm grieving, I'm grieving. I'm really crying. And I saw [the priestess] look at me across the circle, and she saw that I was a mess. And she said to the circle, 'Is there anything else you want to express?' And I just stuck my fist up in the air and I was, like, 'Yhoooooooaaaaaarrrrrrrrrrrrr!!', and just let the rage go, and I was totally like that, 'Oh god! I'm going to be so exposed', and then I did it. And then, as soon as it started to go for me, thirty other people stuck their fist up and did the same thing. So, it was good that other people were feeling...the same way.

Like myself, Erin was a participant whose experience of the Wild Hunt was solitary, and deeply unsettling. Deciding not to take part in the ritual, she sat instead under a tree, in her cloak and, as she described it, shielded in a "glamour", avoiding the fey hounds. In fact, it was precisely the disturbing intention of the ritual that led her to this decision. This was her first Reclaiming witchcamp, and, as she later explained, in the context of her previous experience of sexual abuse at a Pagan event, "going to 
witchcamp and having no idea what I was getting into was a total underworld journey." In the ritual itself, her choice to avoid the hounds stemmed from this fear: "I didn't know the land, didn't know the people, and when I heard hunt, I heard Hunted." And yet, as she explained it, she also chose to remain in the ritual space, rather than going back to her cabin to sit it out. In doing so, she allowed the unsettling character of the ritual to confront her with her fears, precipitating the overspilling of emotion later in the ritual circle: "I wouldn't have thought it at the time, but I think that was part of [the process]."

Erin's cathartic release later in the ritual, and the resonance it found in others' response within the ritual circle, points to how the Wild Hunt's capacity to disturb invites participants into an encounter with what troubles them in their everyday lives including the very personal traumas and griefs of the kind she describes. In line with the themes of unmasking and descent in which Reclaiming ritual work is framed, participants see rituals such as this as permitting them to move beyond their habituated dispositions - which represent a certain accommodation to the destructive realities of their social experience. The emotional excess expressed here speaks to how this ritual helped participants go beyond a merely rational cognition of what disturbs them in their lives, triggering the 'unmasking' process. At the same time, participants see themselves as entering into the 'dark' - in this case the 'underworld' of Anwnn - a place which represents both the frightening and awful, and the potent possibilities through which this fear can be transformed. Thus the Wild Hunt allows us to understand how uncanny ritual elements, through invoking an unsettling atmosphere and making the familiar seem eerie and wild, can at times be used to provoke such a disturbance in participants' habitual consciousness, triggering personal transformation.

The transformative potential of this moment in the witchcamp cycle seems to turn upon a sense of threat brought to life, which brings to consciousness the psychological problems that participants are to address through the course of the week. In fact, according to Bettelheim's analysis, such a moment of threat is central to the psychological value of fairy tales. Adding to Tolkien's four essential components of fairy tales, he states: "I believe that an element of threat is crucial to the fairy tale - a threat to the hero's physical existence or to his moral existence" such that "as soon as the story begins, the hero is projected into severe dangers" (Bettelheim 1977: 144-145). Bettelheim, whose focus is on the value of fairy tales for childhood development, suggests that this threat speaks to the child's experience of life as "a sequence of periods of smooth living which are suddenly and incomprehensibly interrupted as he is projected into immense danger...[such as] when a loving parent suddenly makes what seem like utterly unreasonable demands" (Bettelheim 1977: 145). Yet as we see in the case of Erin's story, his description of the importance of threat to the psychological veracity of the fairy tale seems apposite when applied to adults in the witchcamp context. Whether through wounds retained from childhood or anxieties or traumas experienced as adults, the sense that the 'normal' course of a participant's life is troubled by the internalised scars of living in an estranged society is central to the Reclaiming narrative of healing. Thus rituals such as the Wild Hunt are precisely designed to resonate with this sense of disturbance, to draw it into consciousness in order that it might be transformed. The uncanny of the Wild Hunt foregrounds what is frightening in part as a means of bringing out and reworking the sense of what is disturbed and unsettled - what is uncanny - within.

To explain how this process works, it is useful to turn to Lévi-Strauss's analysis of the effectiveness of symbols in ritual healing, which he illustrates using an example of a Cuna ritual designed to aid in a difficult childbirth. ${ }^{16}$ Here, ritual songs lend symbolic form to otherwise inchoate pain, such that:

\footnotetext{
${ }^{16}$ Luhrmann (2001: 127-132) makes a similar point with respect to her analysis of the role of images of violent deity in Paganism.
} 
The cure would consist...in making explicit a situation originally existing on the emotional level and in rendering acceptable to the mind pains which the body refuses to tolerate (Lévi-Strauss 1963: 197).

Two things are worth noting about the Wild Hunt experience, however, which differentiate it from Lévi-Strauss's description. Firstly, ritual participants are as likely to emphasize the somatic dimensions of their experience as the cognitive or symbolic ones, in line with Reclaiming's focus on non-rational, pre-linguistic methods. As we saw in Erin's description, she speaks of having "a big emotional release, and I was crying, and it was very cathartic... And I had rage and, you know, I feel like I moved a lot of energy". Cognitive recognition is understood as valuable for self-awareness and transformation; yet, as Ezzy suggests for the 'Underworld Rite', in the immediacy of ritual these somatic dimensions precede and take precedence over the cognitive ones. Secondly, in many cases, the narrative understanding of an experience follows at some remove from the somatic experience. Erin describes such a process in her account of her response to this ritual:

...I didn't really know at the time, what it was that I was really emoting about. ...it wasn't clear to me, I know I already mentioned that it was about the thing that happened to me at that other camp, but I didn't realise that at the time. And [another friend] sat me down, and I was like, I don't know why I'm feeling this way... And she was like, 'How could you not be triggered in this setting, based on what happened before?'

....and she said that to me, and it made sense, but I didn't really take it in, and I didn't really get it at all. Until I slept on it, and the next morning it was like, yeah, that was what that was really about...

And...I feel like, why in the hell is this coming up for me again, because I've had years of therapy, and I feel OK about it...and I'm not a child, and la, la, la, la...

And I realised at some point that morning that I had really done as much healing work with the Goddess as I possibly could around it... But, that if I really wanted to heal this thing, and move forward in my life, and have a way to relate sexually with men, or even emotionally with men, that I needed to do some work with the God ${ }^{17}$. And so, I decided to invite him in to all the work that I did that week.

The fact that Erin's previous experience of sexual abuse framed the account she gave of Avalon camp suggests that her knowledge of the source of her anxiety that surfaced in this ritual is central to her narrative of the experience. Nevertheless, an indisputable delay exists between her experience of grief and outrage and her recognition of its source, which speaks to the temporal foldings and "negative space" of the uncanny identified by theorists such as Kennedy. Given the centrality of the elusive to uncanny encounters, this gap seems as central to the event as its later resolution, inviting us to pay attention to the process by which such experiences come into form.

Two metaphors used by Reclaiming members are useful for gaining further insight into the process through which ritual encounter with the uncanny seems to draw these experiences to light. The first is the notion of the homeopathic remedy as it was introduced to me in a later Reclaiming class on healing: the idea of absorbing a small dose of an ailment to cure the larger ailment. ${ }^{18}$ In this healing class we were taught to

\footnotetext{
${ }^{17}$ Erin is referring here to a specifically male form of deity.

${ }^{18}$ While the homeopathic metaphor is most salient for interpreting Reclaiming models of healing, it should be noted that this is also the basis of inoculation in Western medicine.
} 
consider a range of homeopathic remedies in this light, and in this particular context, to envision an element of what ailed us - such as sandpaper grinding arthritic joints - in order to cure the ailment. If we understand the uncanny according to Schelling's definition as "something which ought to have remained hidden but has come to light", we can perhaps conceptualize the use of the uncanny in the Wild Hunt as akin to this form of homeopathic remedy. It can be seen as administering an uncanny experience in order to draw out something which has otherwise remained hidden - for example, an experience of trauma which has seemingly already been dealt with exhaustively - which itself could be expected to give rise to its own uncanny effects.

The second metaphor used by Reclaiming members is that of ritual as facilitating a "rearranging" or "shaking loose" of "stuck" parts of the psyche. In rituals and classes, participants are encouraged to move around, to "shake off the worries of the day" at the start, to move and dance to express psychological states. Such processes are seen as marrying the physiological and the psychological, encouraging a person's somatic self which has become stuck in habitual patterns to be reconfigured, in the process bringing to light parts of the psyche that have lain dormant or hidden. This second metaphor is reminiscent of Michael Jackson's phenomenological theorising of the role ritual can play in disrupting a person's habitus. Analysing the wild, mocking and unaccustomed dancing and performance associated with initiation rites in the Sierra Leone community he studied, he suggests:

[T] his disruption of habitus...lays people open to possibilities of behaviour which they embody but ordinarily are not inclined to express...it is on the strength of these extraordinary possibilities that people control and recreate their world, their habitus (Jackson 1983: 335).

This is not simply a case of changing physical patterns in behaviour. Rather, in shifting bodily comportment, such unaccustomed modes of behaviour can be seen as generating new patterns of cognition:

We are all familiar with the way decontraction of muscular 'sets' and the freeing of energies bound up in habitual deformations of posture or movement produce an altered sense of self... My argument is that the distinctive modes of body use during initiation tend to throw up images in the mind whose form is most immediately determined by the pattern of body use (Jackson 1983: 336).

The Wild Hunt ritual, placing participants' bodies into a setting designed to evoke a sense of the uncanny, could be seen as encouraging such a temporary "pattern of body use" which calls to mind anxieties and traumas which themselves have left traces of the uncanny on the bodies and minds of participants. The fact that such experiences in cases such as Erin's may take some time to come to full cognition potentially speaks to their originally inchoate nature and the modes of expression through which they must pass for example, in grief, expressed rage, verbal articulation, quietude or even sleep - for them to take a more recognisable cognitive form. Thus, reversing Lévi-Strauss, we might suggest that the use of the uncanny can render comprehensible to the body pains that the mind refuses to acknowledge, or has otherwise forgotten or neglected.

The shifting quality of emotion expressed in Erin's descriptions, for example from catharsis to equanimity, is a common pattern among witchcamp participants. Such a process of the inchoate taking form is characteristic of the arc of people's camp experiences. Later in the week at the Avalon camp, another participant, Robert, told me about the emotional responses he often has to banal experiences like the "sappy themes" in Hollywood films that are obviously intended to manipulate the emotions: 
I cry at all sorts of inappropriate things. Normally, I don't know why I'm crying. Today in [our] path [class], when we were putting all the negative stuff into the water, I knew why I felt like crying.

Shortly afterwards he commented:

When I told you I don't normally know why I'm crying, and now I do, I never knew that. I didn't even know I was going to say that until I said it.

Robert's double displacement - of not knowing why he is provoked to cry at particular movies, and of not knowing that he was going to tell me that - reflects in a dual sense a process of something hidden coming to light, capturing what Kennedy describes as the "lack, surplus and negative space" associated with uncanny experience. At the end of a witchcamp, the ideal is for practitioners to achieve a sense of restoration, what they describe as a state of "consciousness" or a better "alignment" of their cognitive and somatic selves. Significantly, for Robert, his experience at the later stages of the camp was not that the source of his crying was eliminated, but that he now knew why he was crying - that the cause of the emotional surplus had been brought to the surface in ritual and consciously located by being spoken aloud to me. Among other things, this restoration could be seen as attempting to reduce the uncanny effects of unprocessed anxieties by allowing ritual to give them form.

\section{Social transformation: wildness, awe and religious conviction}

In parallel with this process, ritual encounters with the uncanny appear to play a role in transforming participants' experience of the broader social conditions that they associate with modernity, informing how they relate to both the social and the natural world around them. There are many ways in which this operates, but to explore this, it is first worth recalling the priestess's reference to the Iraqi mother and her children during the ritual trance following the Wild Hunt. Such references, reasonably common during Reclaiming rituals, are set against a backdrop of the Reclaiming cosmology of interconnection, which in Reclaiming has both theological and ethical content. Thus Starhawk writes:

The destruction of the Amazon rain forest changes our weather. The murder of a health-care worker in Nicaragua by the Contras affects our health. And so our health, physical and emotional, cannot be considered out of context (Starhawk 1990: 22).

In the words of Reclaiming author Valentine, practicing ritual and magical techniques allows practitioners to experience this interconnection directly, so that they can come to feel "the passion for justice that comes when we know that what happens to the web of nature also happens to us" (Starhawk and Valentine 2001: 289). The reference to the Iraqi mother and her children can therefore be seen as serving an ethical purpose, pointing ritual participants towards their compassion for and interconnection with those suffering in Iraq, in order to encourage or strengthen ethical and political action against this suffering.

Given the pervasive opposition to US-led wars expressed in Reclaiming rituals, one experience of a first-time camper at the end of this camp stands out as significant. During the week, Julia had spoken to me of how much she felt the witchcamp to be creating a whole new culture. On the last day of camp, she experienced an image of the Guantanamo Bay prison coming to her mind during the path exercises. This unwelcome intrusion into the witchcamp's tranquillity was at the same time seen as a reminder of the troubled conditions of everyday life in the US to which we were about to return. In light of this moment, it seems apposite to draw on anthropologist Allen Feldman's (2005) analysis of the social effects of the prominence of violent images such as the 
2001 World Trade Center disaster, 'Shock and Awe', and Abu Ghraib prison in US media, in order to explore how references to the Iraq war during Reclaiming rituals such as the Wild Hunt are designed to counter the kinds of effects that exposure to such images of violence may have had on ritual participants.

For Feldman, the overdetermined use of such images form part of "visual cultures of risk and threat perception" which arose in the latter part of the twentieth century (Feldman 2005: 206). Pointing to the psychologically perturbing quality of such images, Feldman argues that the culture of risk and protection generated through the discourses surrounding these violent images "unifies culturally dispersed bodies under the symbolic order of a vulnerable yet sovereign national body" (Feldman 2005: 207). He identifies this as part of what he calls the "actuarial gaze" of the state, which simultaneously reproduces the integrity of the personal body and the social body as both sovereign and vulnerable to penetration from external threats such as the terrorist (Feldman 2005: 207). This actuarial gaze forms a rationalising discourse, both totalising and atomising sociality under the sovereignty of the state. ${ }^{19}$

According to Feldman, the distancing effect of the 'expert' knowledge implied by the deployment of these images, combined with its claim to penetrate into every pore of the society in which they are reproduced, creates a gap between these totalising processes and lived experience, which devalues everyday experience (Feldman 2005: 205-206). In his words, the actuarial gaze "replicates the chasm between transcendental sovereignty and the instability of everyday life structures", stratifying the sensory experience of those within the social body from which they are generated (Feldman 2005: 207). The use of the uncanny in the Wild Hunt ritual can be seen as troubling the dispositions created through such distancing, abstracting processes, returning ritual participants to the immediacy of their own lived experience. Having thus disturbed the boundaries around their persons, thereby upsetting the processes binding them within the national social body, practitioners are able to access more immediately the general sense most Reclaiming members hold intellectually of empathy and emotional connection with the Iraqi mother crying for her children.

The irruption of the image of the Guantanamo Bay prison into Julia's mind at the end of the week, and its significance for her and other campers as a reminder of life in the 'mundane' world, points to how removed people's cognitive and emotional dispositions become from the stratifying effects of these violent images after a week at a witchcamp (notwithstanding its uncanny return as the camp drew to a close). Reclaiming references to the lives of Iraqi people in the context of uncanny ritual settings can thus be understood as potentially unsettling and refiguring the effects of sensory abstraction which Feldman associates with the actuarial gaze, allowing practitioners to disrupt any accommodation they may have unwittingly made to what they see as the horrifyingly known of modern society. The use of the uncanny in rituals such as the Wild Hunt opens up in consciousness an awareness of those things that disturb - outside and within the body of the practitioner - which are purported to be known by modern political rationalities, but which cannot in reality be fully known or contained, least of all in the case of the traumatising images of war. In this way, exposure to the uncanny creates a productive dislocation, placing participants at the edge of a split in consciousness between the known-but-troubling and the unknown-hoped-for, allowing the ritual space to create a sense of resolving and moving beyond this divide.

In a broader sense, such a moving beyond is suggested in the way uncanny experiences touch upon ideas of the 'wild' and 'strange', which for many Reclaiming members represent potent possibilities for challenging contemporary social conditions.

\footnotetext{
${ }^{19}$ In this, Feldman draws on Foucault's understanding of the totalising and atomising effects of what he calls modern political "rationalities" (Foucault 1983; see also Foucault 1980: 155), thus linking this analysis to Weber's concept of rationalisation discussed later in this section.
} 
Such ideas play off a trope that opposes 'nature' and 'modernity', with nature seen as a numinous, interconnected wilderness that cannot be tamed despite the encroachments of 'civilisation'. A popular chant in Reclaiming rituals invites participants to:

Humble yourselves in the arms of the wild

You've got to lay down low and

Humble yourselves in the arms of the wild

You've got to ask her what she knows

Another proclaims, "We are wild-eyed witches, we can change the world". In the howling of the hounds and the invocation of wild and fey forces which live under the ground, the uncanny can be seen to evoke experiences of wildness and strangeness which practitioners associate with numinous possibilities, disrupting the sense that all things can be apprehended in a rational manner, and seeming to move them beyond the things that are purportedly 'known' by science and controlled by the institutions of modernity.

In this dimension, the uncanny is a response to what Weber identifies as processes of rationalisation in modernity, which he famously labelled the "disenchantment of the world" (Weber 1991: 155). According to theories developed by a core of Reclaiming's activist-practitioners, disenchantment is central to the shifts that took place in social dynamics in early modernity, which they see as ushering in social systems typified by patterns of alienation and domination. Historian of science and Reclaiming member David Kubrin argues that the social upheavals of early modernity - from colonialism to the witch campaigns to the first appearance of capitalist production - went hand in hand with a scientific revolution which divested the natural world of its animate qualities and marginalised a magical worldview (Kubrin 2002-3). One of the features of this process is a shift from qualitative to quantitative methods of apprehension: a setting aside of the unquantifiable sensuous features of any object under study in favour of those which are amenable to calculation. As Kubrin outlines this worldview:

According to the new cosmology of the mechanical philosophy, matter itself...existing in empty space...is all there is, all that underlies the whole of the sensate world of phenomena. Changes in the phenomenal world all arise out of the "matter and motion" of the underlying molecular or atomic world, each of the atomic or molecular particles in itself having only size, shape, and its state of motion - all quantitative entities - as its attributes. The world, in essence, is colorless, tasteless, soundless, devoid of thought or life. It is essentially dead, a machine (Kubrin 1981: 108).

As Kubrin points out, his analysis is in many ways concomitant with Weber's notion of disenchantment and rationalisation. For Weber, rationalisation involves an understanding of the world as intrinsically subject to rational apprehension, and in particular he points to the application of methods of calculation to apprehending the entire natural world and all social activity (Weber 1991). This does not imply that everything about the world is finally understood. Rather, rationalisation is:

...the knowledge or belief that if one but wished, one could learn it at any time. Hence, it means that principally there are no mysterious incalculable forces that come into play, but rather that one can, in principle, master all things by calculation (Weber 1991: 139).

Against this rationalised understanding, Reclaiming notions of the 'wild' and 'strange' associated with an imaginary which embraces fairy folk, spirits in the land, consciousness in matter, and numinosity in the cosmos are a means of asserting that in fact there are "mysterious incalculable forces that come into play" in the world. As Reclaiming priestess Inanna once explained to me, there are many things in the material world that are not amenable to what she called "scientistic" analysis, which Reclaiming 
practice seeks to apprehend. The Reclaiming use of uncanny settings in rituals such as the Wild Hunt offers an experience of the world that inherently runs counter to such dynamics of rationalisation.

The belief Reclaiming members hold that modern society has given rise to stratifying and rationalising effects upon human consciousness also points us back towards Freud, who likewise saw 'civilisation' as inducing the repressions and displacements that form the basis of uncanny experience (Freud 1961; 1969). ${ }^{20}$ Yet, unlike Freud, Reclaiming members seek to counter these stratifications not only through personal psychological work, but also through challenging the social basis of these experiences, by creating worlds-apart in the woodlands and by seeking to transform their wider social environment. Where Freud viewed the ills of modernity as probably necessary and inevitable (Freud 1961: 7-9), Reclaiming members seek to overcome them, in part through 'recovering' forms of knowledge and sociality they see as predating modernity. This includes embracing patterns of belief that Freud viewed as socially superseded, such as the power of magic and the spiritual animation of the material world. While Freud endorsed the excavation of suppressed personal experiences as part of a path to healing, he did not likewise see value in recovering those "primitive" beliefs he believed had been "surmounted". This bifurcation in Freud's approach to uncanny experience is not apparent in Reclaiming thought, according to which both of these dimensions of the uncanny must be brought into light in order to effect a full transformation of these suppressed experiences.

Uncanniness in rituals operates as a means of engendering in participants a sense of belonging to an interconnected sociality and to a world infused with religious power. This sense of awe - associated with powerful rituals such as those experienced at a witchcamp - can endure well beyond its immediate transformative power. Participants talk about their experiences at witchcamps for weeks and months afterwards, even at times having moments of recalling them in a sensory way, very vividly and immediately in images or feelings, as though they were still in the middle of the witchcamp ritual. ${ }^{21}$ In this light, what is important about a ritual such as this is not simply the effect it has on a participant's immediate disposition, nor the underpinning cosmological assumptions, but the moments of the ritual itself, and what these do to bind participants to a religious community, and to bring forth in them a new sense of themselves in their relationships with their social surroundings and with a natural world infused with numinous power.

To understand the full value of such ritual encounters, it is worth then returning to Otto's depiction of tremoring at the holy and its power to give rise to feelings of religious awe. For Otto, the experience of mysterium tremendum is inseparable from what he calls a feeling of "createdness" or a "consciousness of creaturehood" associated with selfdeprecation, which suggests at the same time an awareness of the transcendent object of holy contemplation:

$[\mathrm{M}] \mathrm{ysticism}$ leads to a valuation of the transcendent object of its reference as that which through plenitude of being stands supreme and absolute, so that the finite self contrasted with it becomes conscious even in its nullity that 'I am naught, Thou art all' (Otto 1923: 21).

\footnotetext{
${ }^{20}$ Castle (1995: 8-15) discusses the relationship between Freud's ontogeny and phylogeny of the uncanny and the centrality of Enlightenment rationalisation to his account.

21 While not all rituals are equally effective or experienced in the same depth, the Wild Hunt represents an example of a ritual with a significant impact for many of those present. One camp teacher told me several years later that participants had often commented to her how memorable and powerful they found this particular ritual to be, much more so than many others that she was originally more excited about.
} 
Both this creaturehood of the self and the transcendence of the numinous are concepts alien to Reclaiming theology. Nevertheless, there is something we can draw from Otto in interpreting the religious impact of a ritual such as the Wild Hunt. The feeling of uncanniness, in its association with the transcendent, can help evoke for participants a sense of something 'wholly other' in amidst the familiar of the woodlands. In the context of a religion such as Reclaiming, in which sacrality is felt to be immanent in the world, this sense of encounter with something 'other' could be seen as particularly important in supporting the understanding among participants that there are "mysterious incalculable forces" in the world, despite the claims of disenchantment. For a religion such as this, which is more self-consciously created than more established and longer-standing religious traditions, this experience of awe at the 'otherness' of the numinous could be seen as especially important in helping cement religious conviction among practitioners.

Likewise, while Reclaiming members see each person as embodying the sacred, and therefore reject any systematic notion of human inferiority to the divine, Otto's outline of the experience of creaturehood nevertheless seems to have some application here. For there is surely something of this creature-feeling expressed by Robert, when he describes not knowing why he cries, in the inchoate emotions that emerge in him - as he put it, almost embarrassingly - in response to manipulative moments in Hollywood movies. ${ }^{22}$ Reclaiming members hope that in their encounter with deity in ritual, they will be able to identify in themselves those dispositions they describe as a sense of 'disconnection' or lack of 'consciousness' that arise systematically amidst their everyday lives, in order that they can then 'reconnect' with the numinous. When the priestess of the trance following the Wild Hunt says "We are destroyer and destroyed", participants are encouraged to experience themselves as imperfect, culpable beings, and therefore to establish in themselves an ideal of the sacred against which they can recognise their imperfections, take stock of them and, through apprehending the sacred, renew themselves in relation to these feelings of culpability. Thus the ritualised encounter with religious dread of the Wild Hunt is a necessary pre-cursor to the ritual signing of a 'new treaty' with the fey the following night, paving the way for participants to commit more fully to this treaty to care for the land in loving relationship. It is in this simultaneous recognition of the awesomeness of the numinous in this encounter, and of their having strayed from full consciousness of that power, that the signing of the treaty becomes an act of responsibility.

Finally, there is a further trace element of the uncanny that is useful for analysing the implications of rituals such as the Wild Hunt: the association of the uncanny with desire pointed to in the work of Kennedy. The ritual use of the uncanny seems to touch on an intense sense of yearning and wonder that Reclaiming members feel for the wilderness, particularly in their love of places such as the Mendocino Woodlands. In fact, as with Kennedy's description of elegy's evocation of unfulfilled desire, this sense of awed wondering at nature in Reclaiming is also fraught with sorrow. Practitioners feel

${ }^{22}$ As Raphael points out, while numinous experience must be understood as thoroughly contextualized by theology and personal experience, it is nevertheless possible to find elements of awe at the sacred 'wholly other' akin to Otto's description within Goddess feminist religions such as Reclaiming (Raphael 1994: 521-522; 1996: 33-34,162-164). Indeed, she argues for the value of incorporating an Ottonian notion of creaturehood and profanity within contemporary progressive theologies that seek to condemn social ills, where this sense of profanity is understood as "historical rather than ontological", a sign of the distance of historically situated human experience from what is considered sacred (Raphael 1997: 187). In line with this, I am suggesting that Reclaiming members do in fact adopt a notion of the profane, as that which is more disconnected from and misaligned with the sacredness of the cosmos, and can have somatic experiences that parallel this at key moments of ritual. 
very keenly the disconnection from the land that they experience as urban-dwellers, particularly living in a society they see as destructive of the natural world. Thus at the start of the Avalon camp, the same priestess who later led the trance following the Wild Hunt spoke to this sense of longing in introducing the path class she planned to teach: 'Taken by the land/Singing the soul back home'. She shed tears as she announced the class's theme to the collection of campers, speaking of her own bittersweet bereavement and wonder at returning to the trees and landscape of California, to those parts of the world to which she felt connected.

The desire and longing Reclaiming practitioners feel for spaces of natural beauty such as the woodlands is very often tinged with the kind of awed melancholy expressed by this priestess. Such feelings of longing and loss are doubtless shaded by the plaguing awareness that these beloved spaces face a pervasive threat of destruction through the pressures of industrialised society. Being in the woodlands is a reminder of both what is and is not - that the woodlands are experienced as a place of beauty and the true home to which practitioners may return, and that they are likewise only a temporary retreat; that after a week, participants must return to the fraught urban spaces that they normally inhabit, spaces that in their concrete, traffic and complexity offer an everpresent reminder of the threats that exist to the wilderness they love. At the same time, in this inchoate melancholy are echoes of the deeper quality of "negative space" identified by Kennedy, raising the question of whether such desire must always be fraught with longing, and whether it is ever possible to completely 'sing the soul back home'. The uncanny, in its link to the "negative space" of unfulfilled desire, can be seen as a way of touching on this experience, drawing participants into ritual encounter with their own longing to come home to the land, and thereby into the wondrous world of spirits and magic to which they feel they 'truly' belong. ${ }^{23}$

\section{Conclusion}

It is a commonplace of modern Paganism that 'where there is fear there is power' and ritual themes involving frightening elements are not uncommon in Reclaiming. Many such frightening encounters fall into a category of what could be called 'uncanny': elements that cause one to 'shudder', which lend the familiar a strangely unfamiliar appearance. As we have seen, this exposure to uncanny elements in ritual can open up what Erin described to me as "cracks in the façade of reality" - disturbing a person's immediately felt embodied experience and disrupting received expectations about the self in the world. Many factors contribute to this process: in this case, the set-apart nature of the woodlands, the expectations participants arrive with, and the habituated pattern of 'descent' and 'return' that shapes the ritual arc of each witchcamp. Within this context, uncanny encounters within ritual can become amplified into significant

\footnotetext{
${ }^{23}$ Such a suggestion of awe and trembling at the sacred as also signalling desire might be seen as troubling for Otto's association of the uncanny with Christianity. In fact, as Dawson points out, Otto's work, like Freud's, points to a "relationship of numinous, aesthetic, and erotic experiences" (Dawson 1989: 284). This is revealed in his account of the second component of numinous experience - the fascinating - of which he says, "These two qualities, the daunting and the fascinating, now combine in a strange harmony of contrasts, and the resultant dual character of the numinous consciousness... is at once the strangest and most noteworthy phenomenon in the whole history of religion" (Otto 1923: 31). While Otto's account depicts these two components as separate experiences collocated in the numinous by happenstance, Kennedy helps us explain them as sharing a common foundation in the uncanny quality of unfulfilled desire. See also Luhrmann's account of Paganism's violent images of deity in terms of Otto and Lacan, whereby she suggests that such a fusion of awe with originary desire allows the religious believer to experience the divine as both "their most profound representation of otherness, as well as their relationship of greatest intimacy" (Luhrmann 2001: 136).
} 
moments of transformation. Such experiences help to shift the sense of what it is for practitioners to feel at home in their own skin, making them uncomfortable in order to call to mind their own amorphous anxiety-inducing experiences. At the same time, this sense of dislocation operates to foreground in consciousness practitioners' sense that all is not well with the world, of what they feel is the deeply troubling character of life in modern society. Through thus evoking their pre-existing experiences of personal and social distress, thereby facilitating transformations in their psychological and social dispositions, ritual encounters with the uncanny can in fact be seen as a means through which participants can come to feel "at home in the uncanny."

Members of religions such as Reclaiming are faced with a multiple burden in establishing the veracity of their religious claims: not only must they make 'real' the sense of numinosity in the material world in the face of disenchantment, and not only must they do this in a context in which their religious traditions are patently and selfconsciously invented, but they do so in a context of overwhelming scepticism, of a generalised social conception of the material world's profanity - a context in which, as Royle so eloquently illustrates, religious beliefs themselves have come to seem uncanny. Thus, looking at the connection drawn by Otto between uncanny experience, religious dread, awe and wonder, we might suggest that perhaps it is this very gap between practitioners' religious belief and their everyday experience that more than anything drives the use of the uncanny in this modern ritual context; perhaps such experience is necessary for crossing the otherwise seemingly unbridgeable chasm between religious doubt and ingenuous belief. Looked at it in this light, Royle and Clack may well be right to suggest that the uncanny comes into being amid the waning of the presumption of universal religious conviction, such that those ritual experiences identified by Otto - of a specifically uncanny form of shuddering - are a response to this context which has made religious experience less unselfconsciously accessible.

In exploring this example of the Wild Hunt ritual, we encounter a dialogical back and forth between religious and non-religious associations of uncanniness, pointing to a surprising complexity in that relationship between uncanniness and religion first signalled in the works of Otto and Freud. Here, uncanniness is neither the sole consequence of an isolated participant's psyche nor the exclusive condition of the numen, but a stretching out of absence and excess, of fracture and folding temporality that opens up in the religious encounter. In this ritual, uncanny experience appears as more than simply a phenomenon with which humans are passively confronted, whether through the inherent nature of the numinous, as in Otto, or through their own repressed anxieties, as in Freud. Rather, the uncanny is also used as a ritual tool, consciously deployed as a response to the traumas and anxieties generated through dislocations in participants' personal and social experiences, in an active process designed to transform these inchoate experiences and to explore the nature of numinous experience. While this idea of the category of the uncanny as a human contrivance has been more readily appreciated with regard to literature and performance, this has been less clear in appreciating its relationship to religion. Yet recognising this performative dimension of the relationship of uncanniness and religiosity allows us to see the possibilities for transforming personal and social experiences offered through encounters with the uncanny in religious ritual.

\section{Acknowledgments}

I am grateful to Lindy Orthia, Vanessa de Kauwe, Margaret Jolly, participants at the Space, Time and God workshop at Stanford University, Reclaiming members and anonymous reviewers for their comments on drafts of this paper. This research was funded by the Australian National University and made possible by support from the Department of Anthropology, University of California, Berkeley. 


\section{References}

Bettelheim, Bruno. 1977. The Uses of Enchantment: The Meaning and Importance of Fairy Tales. New York: Vintage Books.

Borghart, Pieter, Christophe Madelein. 2003. The Return of the Key: The Uncanny in the Fantastic. Image and Narrative 3/1. http://www.imageandnarrative.be/inarchive/uncanny/uncanny.htm.

Castle, Terry. 1995. The Female Thermometer: Eighteenth-Century Culture and the Invention of the Uncanny. New York and Oxford: Oxford University Press.

Christ, Carol P, Judith Plaskow. 1979. Womanspirit Rising: A Feminist Reader in Religion. New York: Harper and Row.

Clack, Brian R. 2008. 'At Home in the Uncanny': Freud's Account of Das Unheimliche in the Context of His Theory of Religious Belief. Religion 38: 250-258.

Clifton, Chas. 2006. Her Hidden Children: The Rise of Wicca and Paganism in America. AltaMira Press: Lanham.

Daly, Mary. 1978. Gyn/Ecology: The Metaethics of Radical Feminism. Boston: Beacon Press.

Dawson, Lorne. 1989. Otto and Freud on the Uncanny and Beyond. Journal of the American Academy of Religion 57/2: 283-311.

Epstein, Barbara. 1991. Political Protest and Cultural Revolution: Nonviolent Direct Action in the 1970s and 1980s. Berkeley, Los Angeles and Oxford: University of California Press.

Ezzy, Douglas. 2011a. The Ontology of Good and Evil: Spirit Possession in Contemporary Witchcraft and Paganism. In Summoning the Spirits: Possession and Invocation in Contemporary Religion, ed. Andrew Dawson. London and New York: I.B. Tauris, 179-197. 2011b. An Underworld Rite: A Pagan Re-Enactment of Persephone's Descent into the Underworld. Journal of Contemporary Religion 26/2: 245-259.

Feldman, Allen. 2005. On the Actuarial Gaze: From 9/11 to Abu Ghraib. Cultural Studies 19/2: 203-226.

Foucault, Michel. 1980. The Eye of Power. In Power/Knowledge: Selected Interviews and Other Writings 1972-1977, ed. Colin Gordon. New York: Pantheon Books, 146165.

1983. The Subject and Power. In Michel Foucault: Beyond Structuralism and Hermeneutics, ed. Hubert Dreyfus and Paul Rabinow. Chicago: University of Chicago Press, 208-226.

Freud, Sigmund. 1961. The Future of an Illusion. Trans. James Strachey. In The Standard Edition of the Complete Psychological Works of Sigmund Freud, ed. James Strachey. XXI. London: Hogarth Press, 3-56. Original edition 1927. 1969. Civilization and Its Discontents. Trans. Joan Riviere. Ed James Strachey. London: Hogarth Press. Original edition 1930. 1976. The "Uncanny". Trans. James Strachey. New Literary History 7/3: 619-645. Original edition 1919.

Greenwood, Susan. 2005. The Nature of Magic: An Anthropology of Consciousness. Oxford and New York: Berg.

Hanegraaff, Wouter J. 1996. New Age Religion and Western Culture: Esotericism in the Mirror of Secular Thought. Leiden, New York, Köln: E.J. Brill.

Hauser, Luke. 2003. Direct Action: An Historical Novel. San Francisco: Groundwork. Hutton, Ronald. 1999. The Triumph of the Moon: A History of Modern Pagan Witchcraft. Oxford: Oxford University Press.

Jackson, Michael. 1983. Knowledge of the Body. Man 18/2: 327-345.

Kennedy, David. 2009. The Beyond of the Subject - Mourning, Desire and the Uncanny. Textual Practice 23/4: 581-598. 
Kubrin, David. 1981. Newton's inside Out! Magic, Class Struggle and the Rise of Mechanism in the West. In The Analytic Spirit: Essays in the History of Science, ed. Harry Woolf. Ithaca and London: Cornell University Press, 96-121. 2002-3. Dead on Arrival: The Fate of Nature in the Scientific Revolution. Culture Change 20. http://culturechange.org/issue20/deadonarrival.htm.

Lévi-Strauss, Claude. 1963. The Effectiveness of Symbols. Trans. Claire Jacobson and Brooke Grundfest Schoepf. In Structural Anthropology. New York: Basic Books, 186-205.

Luhrmann, Tanya M. 2001. The Ugly Goddess: Reflections on the Role of Violent Images in Religious Experience. History of Religion 41/2: 114-141.

Masschelein, Anneleen. 2003. A Homeless Concept: Shapes of the Uncanny in TwentiethCentury Theory and Culture. Image and Narrative 3/1. http://www.imageandnarrative.be/inarchive/uncanny/uncanny.htm.

Mountainwater, Shekhinah. 1991. Ariadne's Thread: A Workbook of Goddess Magic. Freedom: The Crossing Press.

Otto, Rudolf. 1923. The Idea of the Holy: An Inquiry into the Non-Rational Factor in the Idea of the Divine and Its Relation to the Rational. Trans. John W. Harvey. London: Oxford University Press. Original edition 1917.

Poland, Lynn. 1992. The Idea of the Holy and the History of the Sublime. The Journal of Religion 72/2: 175-197.

Raphael, Melissa. 1994. Feminist, Constructivism and Numinous Experience. Religious studies 30/4: 511-526. 1996. Thealogy and Embodiment: The Post-Patriarchal Reconstruction of Female Sacrality. Sheffield: Sheffield Academic Press. 1997. Rudolf Otto and the Concept of Holiness. Oxford: Oxford University Press.

Royle, Nicholas. 2003. The Uncanny. New York: Routledge.

Salomonsen, Jone. 2002. Enchanted Feminism: The Reclaiming Witches of San Francisco. London and New York: Routledge. 2009. Witches' Initiation - a Feminist Cultural Therapeutic? In Handbook of Contemporary Paganism, ed. Murphy Pizza and James R. Lewis. Leiden, Boston: Brill, 363-390.

Starhawk. 1982. Dreaming the Dark: Magic Sex and Politics. Boston: Beacon Press. 1990. Truth or Dare: Encounters with Power, Authority and Mystery. San Francisco: HarperSanFrancisco.

Starhawk, Hilary Valentine. 2001. The Twelve Wild Swans: A Journey to the Realm of Magic, Healing and Action. San Francisco: Harper.

Vidler, Anthony. 1992. The Architectural Uncanny: Essays in the Modern Unhomely. Cambridge, Mass. and London: Massachusetts Institute of Technology Press.

Weber, Max. 1991. Science as a Vocation. Trans. H.H. Gerth and C. Wright Mills. In From Max Weber: Essays in Sociology, ed. H.H. Gerth and C. Wright Mills. London: Routledge, 129-156. Original edition 1919.

Williams, Raymond. 1985. The Country and the City. London: The Hogarth Press. 